\title{
Cellular, Subcellular, and Subsynaptic Distribution of AMPA-Type Glutamate Receptor Subunits in the Neostriatum of the Rat
}

\author{
Véronique Bernard, Peter Somogyi, and J. Paul Bolam \\ Medical Research Council, Anatomical Neuropharmacology Unit, University Department of Pharmacology, \\ Oxford University, Oxford OX1 3TH, United Kingdom
}

\begin{abstract}
Glutamate released in the basal ganglia is involved in the expression of clinical symptoms of neurodegenerative diseases like Parkinson's or Huntington's. Neostriatal neurons are the targets of glutamatergic inputs derived from the cortex and the thalamus acting via AMPA-type as well as other glutamate receptors. To determine the location of subunits of the AMPA subclass of glutamate receptors (GluR) in the rat neostriatum, we applied multiple immunocytochemical techniques using anti-peptide antibodies against the GluR1, GluR2/3, and GluR4 subunits at both the light and electron microscopic levels. All medium spiny efferent neurons, some of which were identified as striatonigral neurons, displayed immunoreactivity for GluR1 and GluR2/3 subunits. Double immunofluorescence revealed that at least $70-90 \%$ of parvalbumin-immunopositive GABAergic interneurons were immunoreactive for each of GluR1, GluR2/3, or GluR4 subunits and that at least $40 \%$ of choline acetyltransferase-immunopositive cholinergic interneurons were immunopositive for GluR1 or GluR4 subunits. The majority of nitric oxide synthase-immunopositive neurons had no detectable immunoreactivity for any of the AMPA receptor sub-
\end{abstract}

units. Electron microscopic analysis confirmed the presence of immunoreactivity for GluR 1 and GluR2/3 in the perikarya of spiny neurons and interneurons and GluR4 in perikarya of interneurons only. GluR1 and GluR2/3 subunits were detected in dendrites and spines. A significant population of extrasynaptic receptors was revealed by pre-embedding immunogold labeling along the plasma membranes of perikarya, dendrites, and spines. Receptors were concentrated in the postsynaptic membrane specialization of asymmetrical synapses, as revealed by the postembedding immunogold method. Quantitative analysis demonstrated that immunoreactivity for the GluR1 and GluR2/3 subunits is higher at the periphery than at the middle of the postsynaptic membrane specialization.

Our results demonstrate that AMPA receptor subunits are distributed widely and heterogeneously among striatal neurons and are concentrated on the postsynaptic membrane of asymmetrical synaptic specializations, although extrasynaptic receptors are also present.

Key words: synaptic junction; immunohistochemistry; immunogold; GluR1; GluR2/3; GluR4
Glutamate is the major excitatory neurotransmitter in the CNS. Its involvement in numerous physiological functions during development and in the adult is now well established (Zorumski and Thio, 1992). Moreover, dysfunctions of glutamatergic connections are believed to be involved in the expression of the clinical symptoms of neurodegenerative diseases like Parkinson's or Huntington's (Bergman et al., 1990; Pollak et al., 1993). Indeed, overactivity of glutamatergic neurons of the subthalamic nucleus and changes in glutamatergic transmission in the striatum are linked to motor disorders in Parkinson's disease (Albin et al., 1989; Bergman et al., 1990; Pollak et al., 1993; Blandini et al., 1996). Furthermore, glutamate-induced excitotoxicity has been proposed to be responsible for cell death in neurodegenerative diseases (Young et al., 1988; DiFiglia, 1990; Albin and Greenamyre, 1992).

Received Sept. 4, 1996; revised Oct. 29, 1996; accepted Nov. 4, 1996.

This work was funded by the Medical Research Council (UK). V.B. was supported by a postdoctoral fellowship from the Fondation pour la Recherche Médicale (France) and the Fondation Singer-Polignac (France). We thank Drs. P. C. Emson and I. Charles for their kind donation of NOS antibody; B. K. Hartman and C. Cozzari for the ChAT antibodies; and Mark Bevan, Nicholas Clarke, Jason Hanley, and Zoltan Nusser for their comments on this manuscript. We also thank Caroline Francis, Paul Jays, Frank Kennedy, Liz Norman, and David Roberts for technical assistance.

Correspondence should be addressed to Véronique Bernard, Medical Research Council, Anatomical Neuropharmacology Unit, Oxford University, Mansfield Road, Oxford OX1 3TH, UK.

Copyright (C) 1997 Society for Neuroscience $\quad 0270-6474 / 97 / 170819-15 \$ 05.00 / 0$
The actions of glutamate are mediated via two groups of glutamate receptors (GluR), the ionotropic receptors and the metabotropic receptors. Ionotropic glutamate receptors are subdivided further, on the basis of selectivity for agonists, into NMDA, AMPA, and kainate receptors (see Boulter et al., 1992; Hollmann and Heinemann, 1994; Nakanishi and Masu, 1994). Molecular cloning has demonstrated that these subtypes are structurally distinct and that there are numerous subunits for each subtype. The genes coding AMPA receptor subunits (GluR1-4) have been cloned, and electrophysiological studies on expressed receptors suggest that the functional diversity of AMPA receptors is generated by the combination of different subunits into hetero-oligomeric complexes (Boulter et al., 1990, 1992; Keinänen et al., 1990; Nakanishi et al., 1990; Sommer et al., 1990; Hollmann et al., 1991; Hume et al., 1991; Gasic and Hollmann, 1992; Keller et al., 1992; Brose et al., 1994; Hollmann and Heinemann, 1994; Huntley et al., 1994; Puchalski et al., 1994; Wenthold et al., 1996).

The neostriatum, which is the major division of the basal ganglia, receives extensive glutamatergic inputs derived from virtually the whole cortical mantle and from the parafascicular/ centromedian complex of the thalamus (see Gerfen and Wilson, 1996). Electrophysiological and pharmacological analyses have demonstrated that many of the effects of glutamate in the neostriatum are mediated via AMPA receptors (Galli et al., 1992; Maione et al., 1995; Kita, 1996). Furthermore, in situ hybridiza- 
tion and immunohistochemical experiments have demonstrated that AMPA receptor subunits are expressed abundantly throughout the basal ganglia, including the neostriatum (Petralia and Wenthold, 1992; Tallaksen-Greene et al., 1992; Martin et al., 1993a,b; Sato et al., 1993; Tallaksen-Greene and Albin, 1994; Bernard et al., 1996; Chen et al., 1996; Ghasemzadeh et al., 1996). It is also clear that different populations of neurons in the neostriatum differentially express AMPA receptor subunits. However, results of the immunocytochemical studies have provided conflicting data on the AMPA receptor subunit composition of different subpopulations of striatal neurons (Tallaksen-Greene et al., 1992; Martin et al., 1993b; Tallaksen-Greene and Albin, 1994; Chen et al., 1996). The first aim of the present study was therefore to characterize, on neurochemical and morphological grounds at both the light and electron microscopic levels, the classes of striatal neurons expressing different subunits of the AMPA receptor by using a variety of immunocytochemical approaches.

The effects of glutamate on postsynaptic structures depend not only on the subtype of receptor and profile of subunits expressed by the postsynaptic neuron but also on their spatial relationship to the glutamate release sites. In this respect, it has been shown that subtypes of glutamate receptors exhibit specific spatial relationships to synaptic specializations and afferent synaptic terminals. Ionotropic receptors are frequently located within the postsynaptic membrane specialization (Baude et al., 1995; Popratiloff et al., 1996), whereas metabotropic receptors are located at a perisynaptic position (Baude et al., 1993; Nusser et al., 1994; Lujan et al., 1996), but both receptor types also occur at a lower density in the extrasynaptic membrane. In the cortex and in the organ of Corti, AMPA receptors have been reported to be concentrated at the periphery of the postsynaptic membrane (Kharazia et al., 1996; Matsubara et al., 1996). In the neostriatum, the precise subcellular and subsynaptic location of AMPA receptors is unknown. The second aim of this study was therefore to examine the subcellular and subsynaptic distribution of AMPA subunits in the neostriatum and to determine their relationships to known glutamatergic afferents.

\section{MATERIALS AND METHODS}

Animals and tissue preparation. Wistar rats (200-250 gm; Charles River, UK) were used in this study. Environmental conditions for housing of the rats and all procedures that were performed on them were in accordance with the Animals (Scientific Procedures) Act of 1986 and in accordance with the policy on the use of animals in neuroscience research issued by the Society for Neuroscience. They were deeply anesthetized with sodium pentobarbitone (Sagatal, $60 \mathrm{mg} / \mathrm{kg}$, intraperitoneally) and then perfused transcardially with $50-100 \mathrm{ml}$ of $0.9 \% \mathrm{NaCl}$, followed by $250 \mathrm{ml}$ of fixative [3\% paraformaldehyde with $0.2 \%$ glutaraldehyde in $0.1 \mathrm{M}$ phosphate buffer (PB), $\mathrm{pH} 7.4]$ and then with $100 \mathrm{ml}$ of $3 \%$ paraformaldehyde alone, at a rate of $\sim 15 \mathrm{ml} / \mathrm{min}$. The brain was removed quickly, and sections from neostriatum were cut on a vibrating microtome at $\sim 70 \mu \mathrm{m}$ and collected in PBS (0.01 M phosphate, $\mathrm{pH}$ 7.4). To enhance the penetration of the immunoreagents, the sections were equilibrated in a cryoprotectant solution (PB $0.05 \mathrm{M}, \mathrm{pH} 7.4$, containing $25 \%$ sucrose and $10 \%$ glycerol) and freeze-thawed by freezing in isopentane (BDH Chemicals, Poole, UK) that was cooled in liquid nitrogen and then in liquid nitrogen and thawing in PBS (von Krosigk and Smith, 1991). The sections were then preincubated in $4 \%$ normal goat serum (NGS) in PBS for $30 \mathrm{~min}$ at room temperature (RT).

Immunohistochemistry. Immunoreactivity for AMPA receptor subunits was detected by using three polyclonal antibodies [GluR1 (AB1504), GluR2/3 (AB1506), GluR4 (AB1508); Chemicon, Temecula, CA]. These antibodies were raised in rabbit against synthetic peptides derived from intracellular sequences of the subunits (Wenthold et al., 1992). They have been characterized and widely used for immunohistochemical studies (Tachibana et al., 1994; Bernard et al., 1996; Matsubara et al., 1996; Popratiloff et al., 1996; Wenthold et al., 1996). Specificity of the antibod- ies has been described in detail (Wenthold et al., 1992). Anti-GluR1, GluR2/3, and GluR4 antibodies recognize GluR1, GluR2 and GluR3 (GluR2/3), and GluR4 subunits of the AMPA receptor, respectively.

Pre-embedding immunoperoxidase method. The sections were incubated in primary antibody solutions (GluR1 and GluR4, $2 \mu \mathrm{g} / \mathrm{ml}$; GluR2/3, 1 $\mu \mathrm{g} / \mathrm{ml}$ ) diluted in PBS that was supplemented with $1 \% \mathrm{NGS}$ for $15 \mathrm{hr}$ at RT with constant gentle shaking. Alternatively, sections were incubated in a cocktail of GluR1, GluR2/3, and GluR4 antibodies at the dilutions mentioned above. They were washed $(3 \times$ PBS) and incubated in biotinylated goat anti-rabbit IgG (1:100, Vector Laboratories, Peterborough, $\mathrm{UK})$ for $1.5 \mathrm{hr}$ at RT. The sections were washed $(3 \times \mathrm{PBS})$ and incubated in an avidin-biotin-peroxidase complex (ABC; 1:100, Vector) for $1.5 \mathrm{hr}$ at RT. After washing [ $2 \times$ PBS and $1 \times$ Tris buffer (TB) $0.05 \mathrm{M}, \mathrm{pH} 7.6$, peroxidase was revealed by incubation in $\mathrm{H}_{2} \mathrm{O}_{2}(0.0048 \%)$ in the presence of $3,3^{\prime}$-diaminobenzidine (DAB; $0.05 \%$ in TB) (Sigma, UK). The reaction was stopped by several washes in TB.

Pre-embedding immunogold method. The pre-embedding immunogold method was performed as previously described (Baude et al., 1993; Yung et al., 1995). Briefly, the sections were incubated in primary antibody solutions as described above. After washing $[2 \times$ PBS and $2 \times$ PBS supplemented with $0.5 \%$ bovine serum albumin and $0.1 \%$ gelatin (PBSBSA)], they were incubated in goat anti-rabbit IgG conjugated to colloidal gold (1.4 nm diameter, Nanogold, Nanoprobes, Stony Brook, NY) (1:100 in PBS-BSA) for $2 \mathrm{hr}$ at RT. The sections were washed $(2 \times$ PBS-BSA and $2 \times$ PBS) and post-fixed in $1 \%$ glutaraldehyde in PBS for $10 \mathrm{~min}$. After washing $(2 \times$ PBS and $2 \times$ sodium acetate buffer, $0.1 \mathrm{M}, \mathrm{pH}$ 7.0), the colloidal gold labeling was intensified by using a silver enhancement kit (HQ silver, Nanoprobes) for 3-5 min at RT in the dark. Finally, the sections were washed in acetate buffer and then in PB.

Preparation for electron microscopy. Immunoperoxidase- and immunogold-treated sections were post-fixed in osmium tetroxide (1\% in PB $0.1 \mathrm{M}, \mathrm{pH} 7.4$ ) for $25 \mathrm{~min}$ for the DAB-reacted sections or $10 \mathrm{~min}$ for the immunogold-reacted sections at RT. After washing $(3 \times \mathrm{PB})$, they were dehydrated in an ascending series of dilutions of ethanol, which included $1 \%$ uranyl acetate in $70 \%$ ethanol. Then they were treated with propylene oxide (2 times for $10 \mathrm{~min}$ ) and equilibrated in resin overnight (Durcupan ACM, Fluka, Neu-Ulm, Germany), mounted on glass slides, and cured at $60^{\circ} \mathrm{C}$ for $48 \mathrm{hr}$. The sections were examined first in the light microscope. Areas of interest were cut from the slide and glued to blank cylinders of resin. Serial thin sections were cut on a Reichert Ultracut E and collected on pioloform-coated single-slot copper or gold grids. The sections were stained with lead citrate and examined in a Philips CM10 electron microscope.

Postembedding immunogold method. After perfusion as described above, $500-\mu \mathrm{m}$-thick sections were embedded in Lowicryl, as described by Baude et al. (1993). Immunohistochemistry was performed on ultrathin sections of the neostriatum collected on pioloform-coated gold grids. The sections were incubated on drops of PBS supplemented with $20 \%$ NGS and $0.5 \%$ cold fish gelatin for $45 \mathrm{~min}$ at RT, and then incubated on drops of primary antibody solutions (GluR1, GluR2/3, and GluR4: $5 \mu \mathrm{g} / \mathrm{ml}$ in PBS with 5\% NGS and $0.5 \%$ cold fish gelatin) for $15 \mathrm{hr}$ at RT. After several washes in PBS, the sections were incubated in goat anti-rabbit IgG conjugated to colloidal gold (1.4 nm, 1:100; Nanoprobes). After washing in PBS, the sections were post-fixed in $2 \%$ glutaraldehyde in PBS for 2 min. They were washed in water, and the labeling was silver-intensified with a silver enhancement kit (HQ Silver, Nanoprobes) for $5 \mathrm{~min}$. After being washed in water, they were incubated in $1 \%$ uranyl acetate in water for $25 \mathrm{~min}$, again washed in water, lead-stained, and dried.

Double immunofluorescence. Sections of the neostriatum were subjected to a double-immunofluorescence procedure to identify the AMPA receptor subunits expressed by different populations of striatal interneurons. Three main populations of striatal interneurons were examined: cholinergic neurons, identified using a mouse monoclonal antibody against choline acetyltransferase (ChAT; Cozzari et al., 1990); GABAergic interneurons, identified using a mouse monoclonal antibody against parvalbumin (PV; SWant, Switzerland) (Cowan et al., 1990; Kita et al., 1990); and the population of interneurons that express somatostatin, neuropeptide $\mathrm{Y}$, and nitric oxide synthase (NOS), identified using sheep antibodies against NOS (Herbison et al., 1996). Briefly, after perfusionfixation as described above, $70-\mu \mathrm{m}$-thick sections were cut and incubated in $4 \%$ NGS or normal horse serum (NHS) for $30 \mathrm{~min}$ and then in a mixture of antibodies against AMPA receptor subunits $(2 \mu \mathrm{g} / \mathrm{ml}$ each $)$ and ChAT $(0.5 \mu \mathrm{g} / \mathrm{ml})$, PV $(1: 1000)$, or NOS $(1: 20,000)$ in PBS supplemented with $1 \%$ NGS or NHS for $15 \mathrm{hr}$ at RT. Then the sections were washed in PBS and incubated in a mixture of secondary antibodies [goat 
anti-rabbit (GAR) for GluR, goat anti-mouse (GAM) for ChAT, and PV or donkey anti-sheep (DAS) for NOS], conjugated to different fluorochromes. The fluorochromes used were fluorescein isothiocyanate (FITC)-labeled GAM (Sigma) and tetramethylrhodamine isothiocyanate (TRITC)-labeled GAM (Sigma) or DAS (Chemicon) to detect AMPA receptor subunits and ChAT, PV, or NOS, respectively. Alternatively, TRITC and FITC were used to detect AMPA receptor subunits and ChAT, PV, or NOS, respectively. All of the secondary antibodies were used at a dilution of 1:100. After washing, the sections were mounted in Aquamont (BDH Chemicals) and examined by fluorescence microscopy with filters selective for fluorescein or rhodamine.

Controls of specificity of the immunohistochemical labeling. The specificity of the labeling technique was proven by the absence of labeling for the respective molecules when the primary antibody (single detection) or when one or both primary antibodies (double detection) were omitted.

Retrograde labeling combined with immunohistochemical detection of AMPA receptor subunits. To determine whether striatonigral neurons express AMPA receptor subunits, we combined immunohistochemistry for the receptor subunits with the retrograde transport of wheat germ agglutinin-horseradish peroxidase complex (WGA-HRP). Two female Wistar rats (200 gm; Charles River) were anesthetized with a mixture of midazolem (Hypnovel, Roche Products, Hertfordshire, UK) and fentanyl citrate and fluanisone (Hypnorm, Janssen Animal Health, Buckinghamshire, UK) and placed in a stereotaxic frame. The WGA-HRP (40 $\mathrm{nl}$ of $5 \%$ solution in $0.9 \%$ saline; Sigma) was injected in the substantia nigra (SN) using coordinates taken from the atlas of Paxinos and Watson (1986). The coordinates were anteroposterior (from bregma), $-5.3 \mathrm{~mm}$; lateral, $+2 \mathrm{~mm}$; dorsoventral, $-7.9 \mathrm{~mm}$ (from the surface of brain). The animals were perfused $24 \mathrm{hr}$ after surgery as described above. Sections (70 $\mu \mathrm{m}$ thick) of neostriatum and substantia nigra were cut on a vibrating microtome and were processed immediately to reveal the injected and transported WGA-HRP using the TMB-molybdate technique (Olucha et al., 1985). They were washed in TB (0.1 M, $\mathrm{pH} 6.2)$ and incubated in TMB [ $1 \mathrm{mg}$ in $0.25 \%$ ammonium molybdate tetrahydroborate and $0.003 \%$ $\mathrm{H}_{2} \mathrm{O}_{2}$, in $\left.\mathrm{PB}(0.1 \mathrm{M}, \mathrm{pH} 6.2)\right]$ for $40 \mathrm{~min}$. The reaction was stopped by several washes in $\mathrm{PB}$, and the reaction product was stabilized with $0.1 \%$ $\mathrm{DAB}$ and $0.01 \% \mathrm{CoCl}_{2}$ in $\mathrm{PB}$ at $\mathrm{pH}$ 7.4. Then the sections were washed in PBS for $1 \mathrm{hr}$ and processed for the detection of AMPA receptor subunits by using the immunoperoxidase method, followed by preparation for electron microscopy as described above. The sections were embedded in resin and mounted on glass slides. Blocks of neostriatum were re-embedded, and semithin sections $(2 \mu \mathrm{m})$ were cut and examined in the light microscope.

Quantitative analysis. The proportions of interneurons, identified by immunoreactivity for ChAT, PV, or NOS, displaying immunoreactivity for the AMPA receptor subunits were determined on one or two sections of neostriatum from at least four rats at the same level in the rostrocaudal axis $[\sim 1 \mathrm{~mm}$ anterior of bregma according to Paxinos and Watson (1986)]. All ChAT-, PV-, or NOS-immunoreactive neurons were identified in the fluorescence microscope by using the appropriate filter systems to detect fluorescein or rhodamine; the proportion of these showing AMPA receptor subunit immunofluorescence was established. Control experiments did not show cross-recognition between the two fluorochrome-labeled reagents.

Quantitative analysis of the subcellular distribution of GluR1 and GluR2/3 immunoreactivity was performed at the electron microscope level on immunoperoxidase sections of the neostriatum from three animals. To quantify the total AMPA receptor subunit immunoreactivity, we also performed the same analysis on sections incubated with a cocktail of antibodies to GluR1, GluR2/3, and GluR4. The analysis was performed on series of adjacent micrographs at a final magnification of $13,500 \times$. A total of 97 micrographs, occupying an area of $3 \times 10^{-3} \mathrm{~mm}^{2}$ of sections that were treated for the detection of GluR1 or GluR2/3. Thirty-one micrographs $\left(0.96 \times 10^{-3} \mathrm{~mm}^{2}\right)$ showing the total AMPA receptor subunit immunoreactivity for GluR1 + GluR2/3 + GluR4 were analyzed from three animals. The sections were all taken from the dorsolateral neostriatum. All dendritic shafts and spines were identified on these micrographs, and the proportion of those displaying immunoreactivity for the receptor subunits was calculated.

To estimate the proportion of asymmetrical axospinous synapses immunopositive for GluR1 and GluR2/3 (immunogold technique), we analyzed two continuous strips of tissue $\left(319 \mu \mathrm{m}^{2}\right.$ each) in Lowicrylembedded sections at a magnification of $13,500 \times$ taken from two animals (1 section per animal).

Quantitative analysis of the distribution of immunogold particles for
GluR1 and GluR2/3 along the postsynaptic membrane specialization was performed on 120 electron micrographs of Lowicryl-embedded neostriatum. In all, 144 synapses and 598 gold particles from two animals were analyzed. Continuous strips of tissue in Lowicryl-embedded sections were analyzed at a magnification of $39,000 \times$, examining synapses in which the synaptic specialization was clear. A synapse was considered as immunopositive when it was associated with two or more immunoparticles (Baude et al., 1995; Popratiloff et al., 1996); all positive synapses in the strip were evaluated in the analysis. The distance of each immunoparticle from the center of each synapse was measured and normalized, to take into account different sizes of synapses, by dividing the value by one-half the width of the synapse. The data were expressed as the proportion of immunoparticles in five bins along the half cross section of the synapse.

\section{RESULTS}

\section{Light microscopic observations}

\section{Immunohistochemical detection of AMPA receptors in} the neostriatum

The neostriatum displayed immunoreactivity for GluR1, GluR2/3, and GluR4, which was evident at low magnification (Fig. 1A,C,E). The staining was homogeneous and without obvious differences between neostriatum and the nucleus accumbens and along the rostrocaudal and dorsoventral axes. Neuropil labeling was detected with antibodies to the GluR1 and GluR2/3 subunits, but not for the GluR4 subunit. At high magnification, in vibratome sections $(70 \mu \mathrm{m})$ (Fig. $1 B, D)$ or in semithin sections $(2 \mu \mathrm{m})$ (Fig. $2 A, B)$, numerous cell bodies and dendrites that displayed immunoreactivity for GluR 1 and GluR2/3 were visible. In contrast, only a few scattered neurons and dendrites displayed immunoreactivity for GluR4 (Figs. $1 F, 2 C$ ). Most of the cell bodies that were immunopositive for GluR1 and GluR2/3, but not for GluR4, were medium-sized with an unindented nucleus surrounded by a thin rim of cytoplasm (Figs. $1 B, D, 2 A, B$ ). These neurons thus had characteristics of medium spiny neurons. In addition to the moderate labeling of medium-sized neurons, strong GluR1 immunoreactivity was detected in occasional neurons throughout the neostriatum (Figs. $1 B, 2 A$ ). These neurons were either mediumor large-sized and had an indented nucleus and thus were characterized as aspiny interneurons. Some medium-sized, but no large-sized, neurons that possessed an indented nucleus also were immunolabeled for GluR2/3 (Fig. 2B). All neurons that displayed immunoreactivity for GluR4, which included both medium- and large-sized, possessed an indented nucleus (Figs. $1 F, 2 C$ ). The pre-embedding immunogold labeling produced a similar pattern of staining to that produced by the peroxidase method, albeit at a lower intensity. No glial cell labeling was observed in the neostriatum.

\section{Phenotypes of striatal neurons expressing AMPA receptor subunits}

\section{Identification of the AMPA receptor subunits expressed by} striatonigral neurons

Striatonigral neurons were identified by the retrograde transport of WGA-HRP from the pars reticulata of the substantia nigra. Immunolabeling of the same sections to reveal AMPA receptor subunits demonstrated that all WGA-HRP-positive neurons were also positive for GluR1 or GluR2/3 (Fig. $2 A, B$ ). In contrast, the retrogradely labeled neurons were not immunopositive for GluR4 (Fig. 2C).

\section{Identification of AMPA receptors subunits expressed by striatal interneurons}

Striatal cholinergic, GABAergic, and NOS/NPY/SOM-containing interneurons were identified by using antibodies directed against ChAT, PV, and NOS, respectively (Fig. 3). Double detection of 

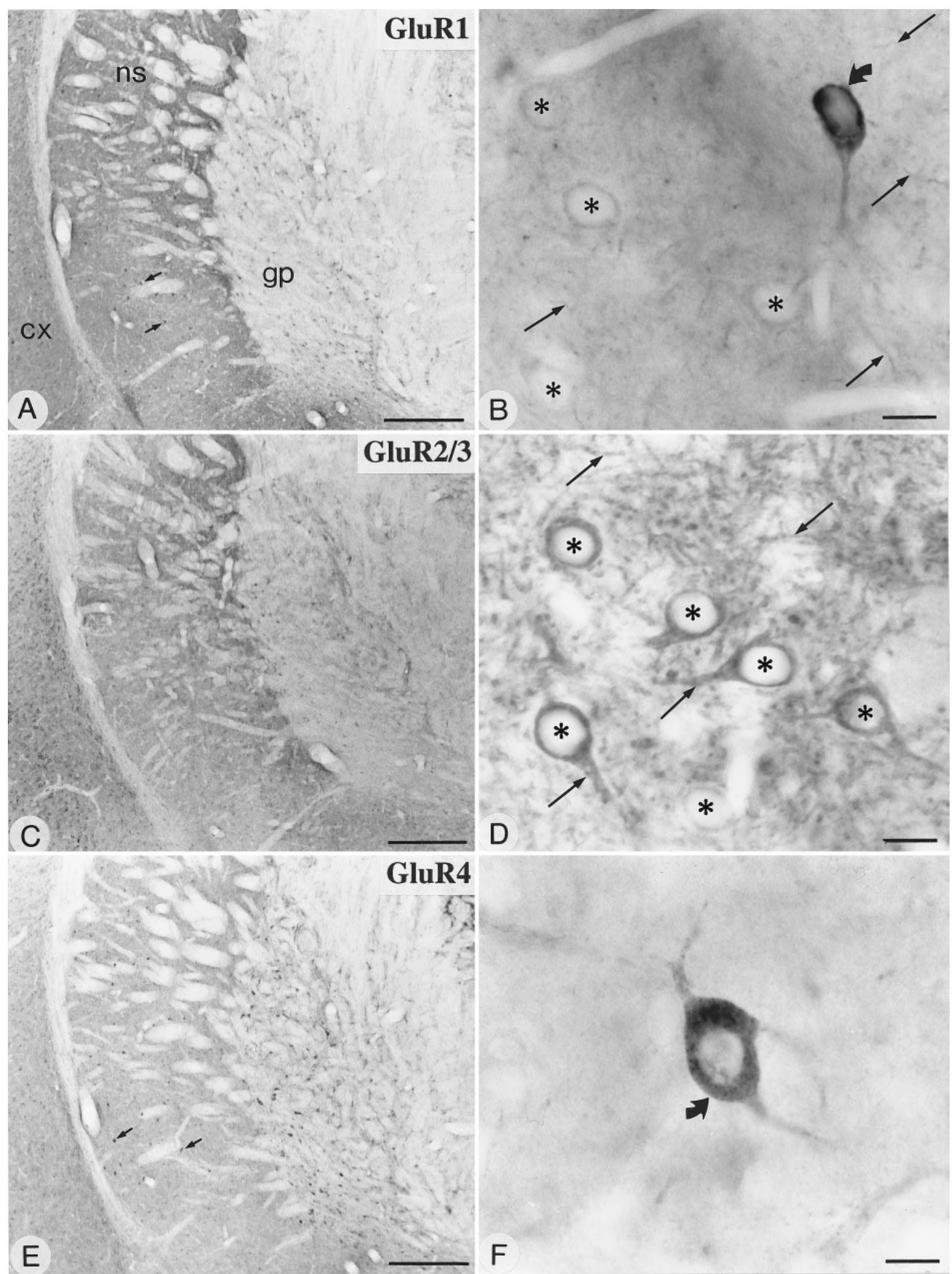

Figure 1. Immunohistochemical detection of GluR1 $(A, B)$, GluR2/3 $(C, D)$, and GluR4 $(E, F)$ in the striatopallidal complex by the peroxidase method at the light microscopic level. The neostriatum $(n s)$ and globus pallidus $(g p)$ display immunoreactivity for GluR1, GluR2/3, and GluR4 subunits of the AMPA receptor. A dense dendritic staining of the neuropil is present in the neostriatum for GluR1 $(A)$ and GluR2/3 $(C)$, but not for GluR4 $(E)$. Strongly labeled cells are identified throughout the neostriatum with GluR1 and GluR4 (some indicated by arrows), but not with GluR2/3 antibodies. Immunoreactivity for GluR1 $(B)$ and GluR2/3 $(D)$ is present in perikarya (asterisks) and dendrites (arrows) of striatal neurons that have characteristic features of spiny neurons. Some aspiny neurons with indented nuclei display strong immunoreactivity for GluR1 $(B)$ and GluR4 $(F)$ (curved arrows). $c x$, Cortex. Scale bars: $A, C, E, 0.5 \mathrm{~mm} ; B, D, F, 10 \mu \mathrm{m}$. 

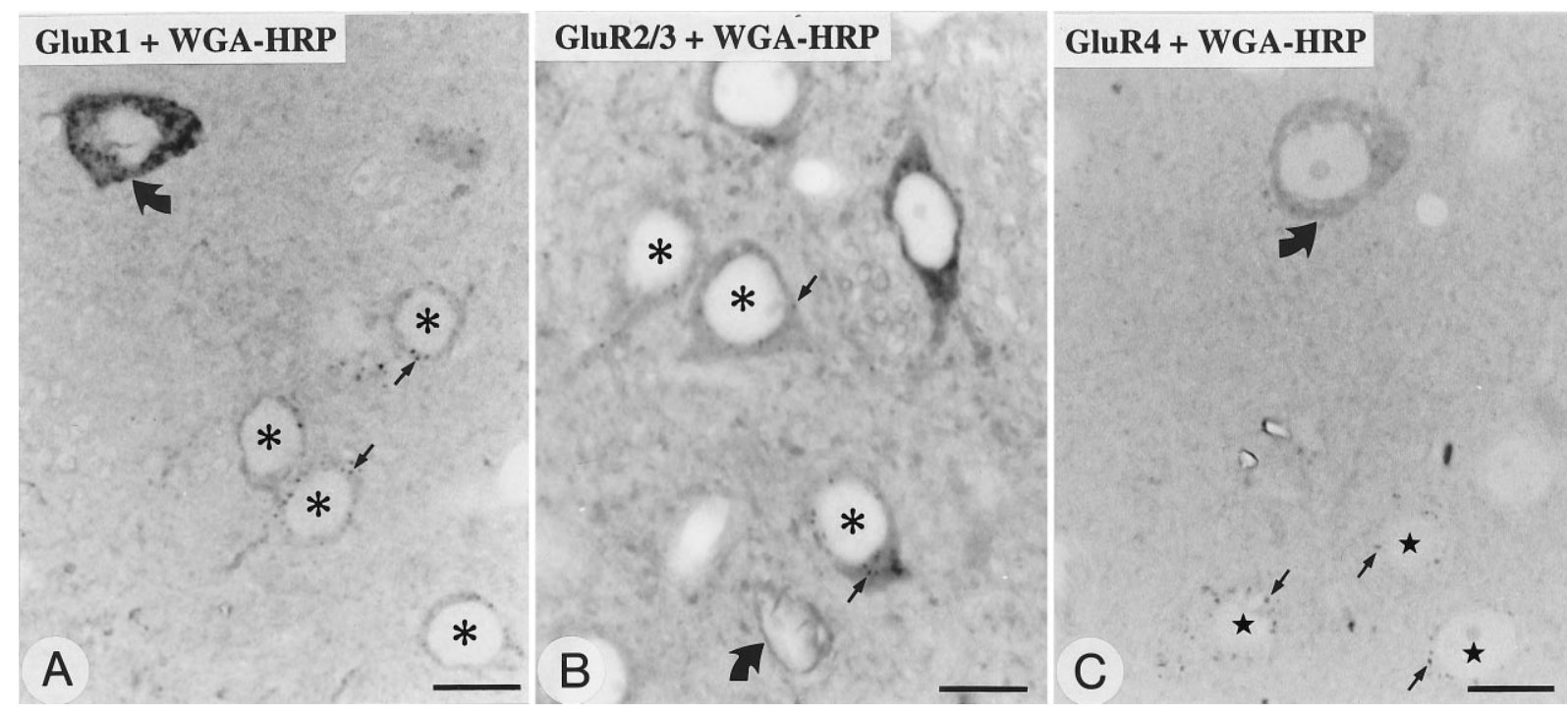

Figure 2. Identification of AMPA receptor subunits expressed by striatonigral neurons. Combination of the immunohistochemical detection of AMPA receptor subunits with the retrograde transport of WGA-HRP from the SN. Immunoreactivity for the receptor subunits was revealed by the immunoperoxidase method with DAB as the chromogen, and the transported WGA-HRP was revealed by using TMB-molybdate as the chromogen. Retrogradely labeled neurons containing granules of the peroxidase reaction product (some indicated by small arrows) also display immunoreactivity for GluR1 $(A$, asterisks) and GluR2/3 (B, asterisks), but not GluR4 (C, stars). Note the neurons (curved arrows in each micrograph) that possess characteristics of interneurons. Scale bars, $10 \mu \mathrm{m}$.

AMPA receptor subunits and ChAT, PV, and NOS was performed by double fluorescence with secondary antibodies conjugated to FITC or TRITC. In all, 508 ChAT-positive neurons, 1016 PV-positive neurons, and 507 NOS-positive neurones were examined from four rats.

The majority of PV-positive neurons that we identified $(89,69$, and $86 \%$ ) were immunopositive for GluR1, GluR2/3, and GluR4, respectively (Fig. 3). In all, 41 and $40 \%$ of ChAT-positive neurons that were identified were also positive for GluR1 and GluR4, respectively (Fig. 3). In contrast, none of the ChAT-positive neurons displayed GluR2/3 immunoreactivity. Only few (5 and $3 \%$ ) NOS-immunopositive neurons were labeled for GluR1 and GluR2/3, respectively. The NOS-immunopositive neurons were negative for GluR4. The control experiments revealed that the primary antibodies were recognized only by the appropriate secondary antibodies.

\section{Electron microscopic observations}

The subcellular localization of AMPA receptor subunits was performed by pre-embedding immunoperoxidase and pre- and postembedding immunogold methods. The electron microscopic analysis confirmed the light microscopic observations that GluR1 and GluR2/3 are expressed by medium spiny neurons and interneurons and that GluR4 is expressed only by interneurons.

The immunoperoxidase reaction product was associated with the membranes of subcellular organelles (Figs. 4, 6B, 7A) and also diffusely filled the labeled profiles. The most frequently labeled structures for GluR1 and GluR2/3 were dendrites and spines (Figs. 4, 6B), although some perikarya and occasional axons were also labeled (data not shown). Of 612 dendrites of medium spiny neurons or interneurons and 405 spines receiving synapses in immunoperoxidase-labeled sections, 70 and $74 \%$ of dendrites and 58 and $50 \%$ of spines were immunopositive for GluR1 and GluR2/3, respectively. In contrast, only few dendrites were immunolabeled for GluR4 (Fig. 7A), and labeling was not detected in spines. When a cocktail of GluR1, GluR2/3, and GluR4 antibod- ies was used, $72 \%$ of dendrites and $62 \%$ of spines were clearly immunopositive. The values obtained from the three animals were very similar (mean of percentages of labeled profiles from the 3 animals \pm SEM); dendrites: $70 \pm 4$ (GluR1), $74 \pm 3$ (GluR2/3), $72 \pm 2$ (GluR1 + GluR2/3 + GluR4); spines: $58 \pm 3$ (GluR1), $50 \pm 1$ (GluR2/3), $62 \pm 6($ GluR $1+$ GluR2/3 + GluR4). However, those figures are likely to be underestimates, because the proportion of immunolabeled profiles obtained with this method depends on the penetration of the reagents into the tissue and the depth in relation to the surface of the tissue that the sections were taken. False negatives are thus likely to be encountered. All the immunolabeled spines were contacted by boutons forming asymmetrical synapses (Figs. 4B, 6B).

In the pre-embedding immunogold-labeled sections, the same subcellular structures were labeled as in the immunoperoxidasereacted sections. Immunoparticles for GluR1 and GluR2/3 were detected in numerous dendrites and spines (Figs. $5 B-D, 6 C-E$ ), whereas those for GluR4 were seen only in some dendrites (Fig. 7D). In dendrites and spines, most of the immunoparticles were present on the cytoplasmic face of the plasma membrane for each of the AMPA receptor subunit antibodies (Figs. $5 B-D, 6 C-E, 7 D$ ).

Immunolabeling for AMPA receptor subunits was also detected in perikarya (Fig. $5 A, 6 A, 7 B, C$ ). Two types of cell bodies immunolabeled for GluR1 were identified. Neurons of the first type were weakly stained neurons and had characteristics of medium spiny neurons, i.e., with an unindented nucleus and a thin rim of cytoplasm that was sparse in organelles. The second type of cell body immunoreactive for GluR1 was strongly labeled and had hallmarks of aspiny interneurons, i.e., possessed an indented nucleus, a large volume of cytoplasm (Fig. $5 A$ ), and occasional intranuclear inclusions. Immunolabeling for GluR2/3 was detected in medium spiny neurons and in some interneurons (Fig. 6A). GluR4 labeling was seen only in interneurons (Fig. $7 B, C$ ). For each antibody and each cell type, aggregations of peroxidase reaction product were seen in the cytoplasm often associated with the endoplasmic reticulum and on the cytoplasmic 


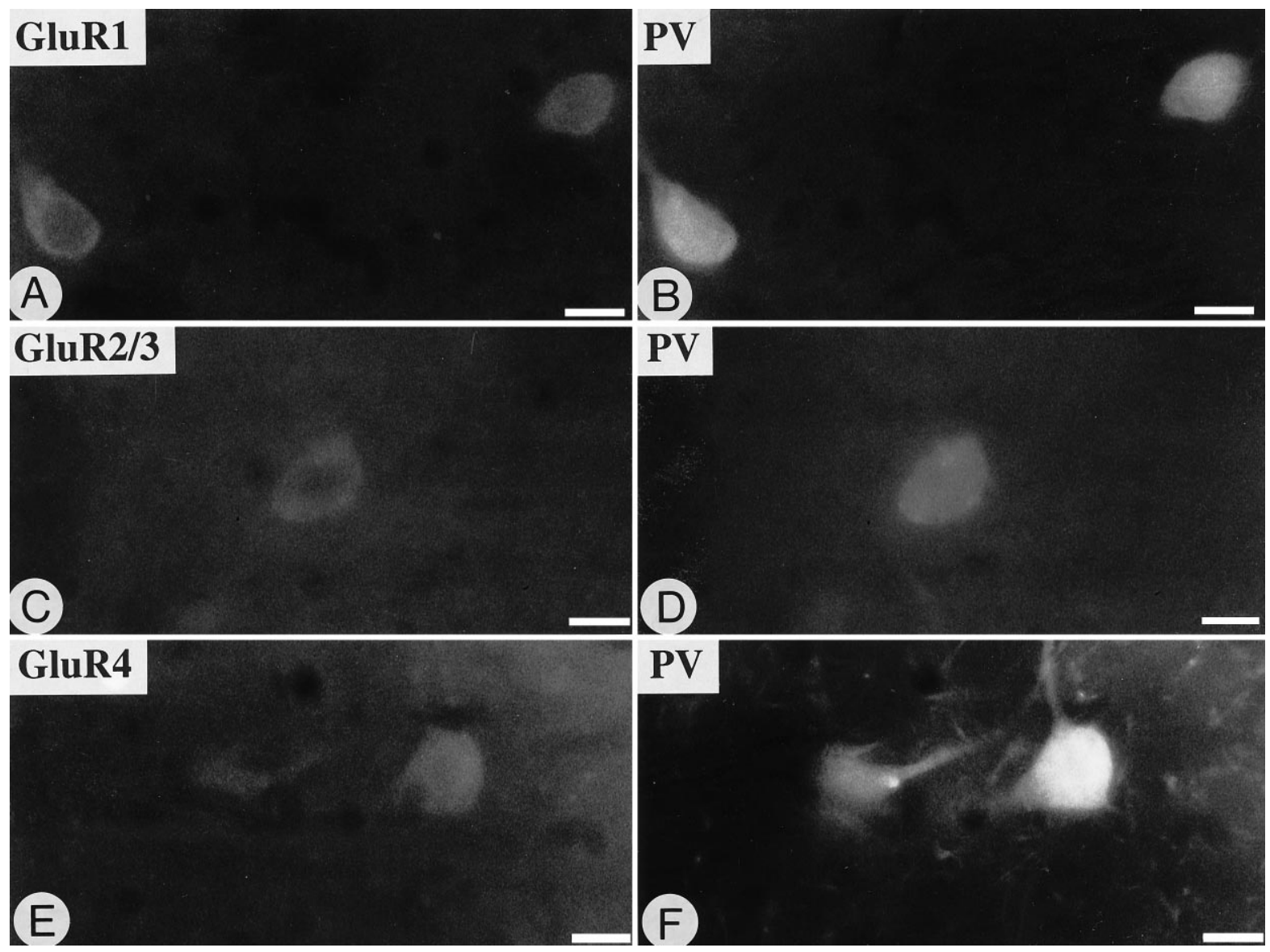

Figure 3. Identification of AMPA receptor subunits expressed by GABAergic interneurons using a double-immunofluorescence method. GABAergic interneurons were identified by using antibodies against parvalbumin $(P V)$. PV-immunoreactive neurons $(B, D, F)$ also display immunoreactivity for GluR1 $(A)$, GluR2/3 $(C)$, and GluR4 $(E)$. Scale bars, $10 \mu \mathrm{m}$.

Table 1. Proportions of GABAergic (PV-immunopositive), cholinergic (ChAT-immunopositive), and NOS-immunopositive interneurons displaying immunolabeling for each of the antibodies to AMPA receptor subunits.

\begin{tabular}{llrr}
$\begin{array}{l}\text { Type of } \\
\text { interneuron }\end{array}$ & AMPA receptor subunits & & \\
\cline { 2 - 4 } & GluR1 & GluR2/3 & GluR4 \\
\hline PV-immunoreactive neurons & $89 \pm 7(n=376)$ & $69 \pm 3(n=321)$ & $86 \pm 4(n=319)$ \\
ChAT-immunoreactive neurons & $41 \pm 5(n=168)$ & $0(n=74)$ & $40 \pm 4(n=156)$ \\
NOS-immunoreactive neurons & $5 \pm 1(n=187)$ & $3 \pm 1(n=167)$ & $0(n=153)$ \\
\hline
\end{tabular}

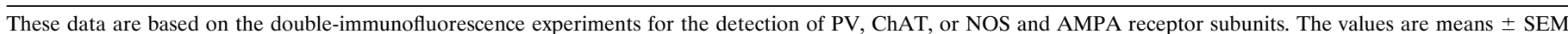

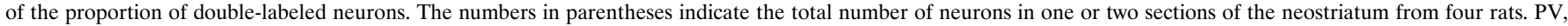
Parvalbumin; ChAT; choline acetyltransferase; NOS, nitric oxide synthase.

side of the nuclear membrane (Fig. $7 B$ for GluR4). In the preembedding immunogold-labeled sections, immunogold particles were abundant and associated with the cytoplasmic face of the endoplasmic reticulum membrane and nuclear membrane (Figs. $5 A$, $6 A, 7 C)$. Immunoparticles were also located on the cytoplasmic side of the plasma membrane (Figs. $5 A, 6 A, 7 C$ ).

\section{Localization of AMPA receptor subunit immunoreactivity in relation to synaptic junctions}

The use of pre- and postembedding immunogold methods allowed the precise localization of the sites of AMPA receptor subunit immunoreactivity, particularly in relation to the glutamate release sites.

\section{Pre-embedding immunogold method}

For each of the antibodies used, the majority of immunoparticles was associated with the internal surface of the plasma membrane (Figs. 5, 6A, $C-E, 7 C, D$ ), both at sites away from synaptic junctions and at synaptic sites. Many immunoparticles were associated with asymmetrical synaptic contacts (Figs. $5 B-D, 6 C-E, 7 D$ ). In dendritic spines that displayed immunoreactivity for GluR1 (Figs. $5 B, D$ ) and GluR2/3 (Figs. $6 C-E$ ), the immunoparticles were observed most commonly at the edges of the asymmetric membrane specialization of the spines, which receive synapses from terminals containing round vesicles, and also on the membrane at extrasynaptic sites (e.g., Fig. 6C). However, immunoparticles occasionally were located on the postsynaptic membrane density within the 

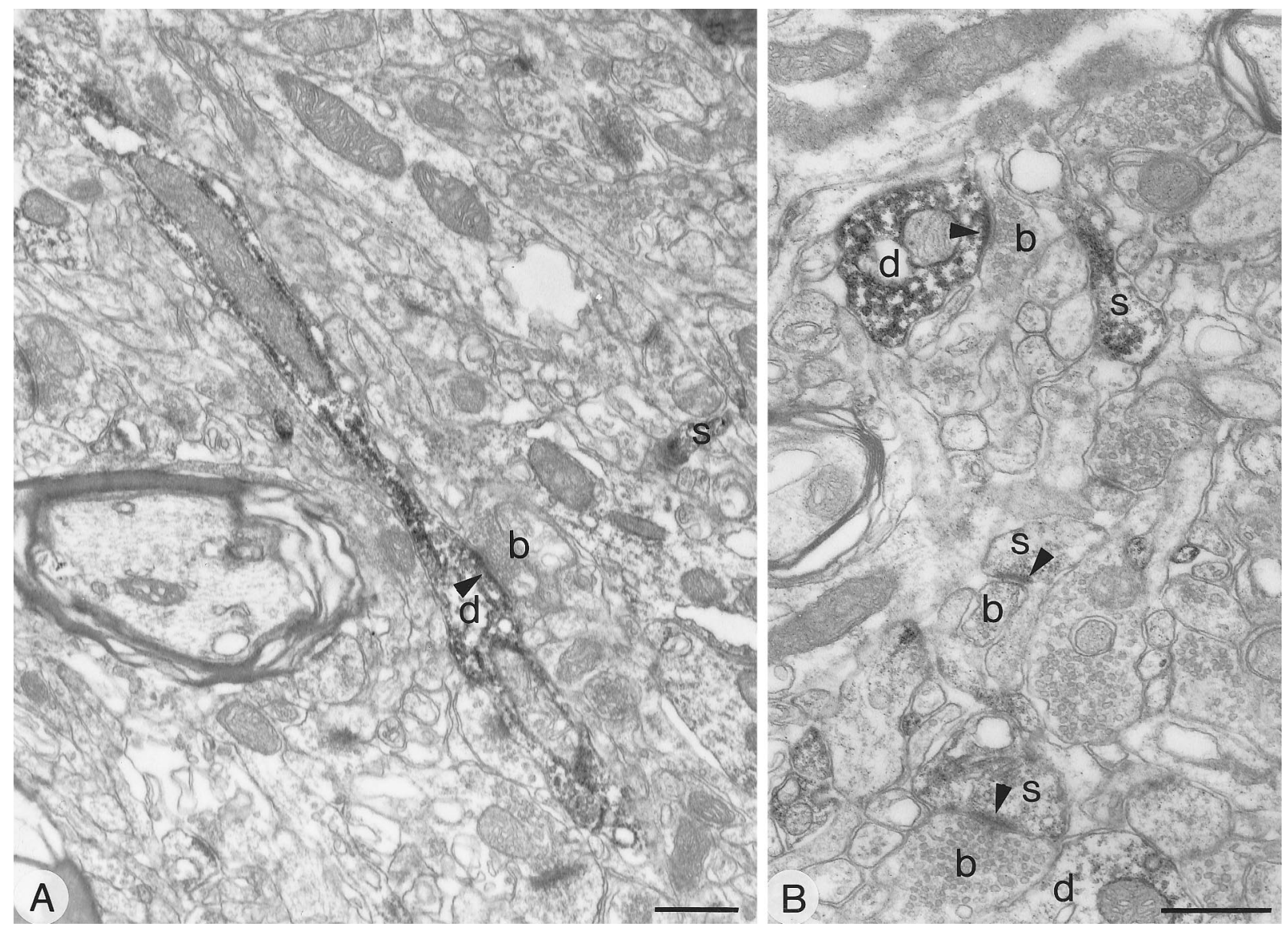

Figure 4. Subcellular localization of GluR1 in the neostriatum using the immunoperoxidase method. $A, B$, Reaction product is detected in dendrites $(d)$ and in spines $(s)$. The immunoreactive structures often are associated with axonal boutons $(b)$ forming synapses (arrowheads), some of which are clearly asymmetrical. Scale bars, $0.5 \mu \mathrm{m}$.

synaptic specialization (Figs. $5 B, 6 E$ ). Immunolabeling for GluR1 (Fig. 5C,D) and GluR4 (Fig. 7D) AMPA receptor subunits was associated with the membrane of postsynaptic dendrites receiving asymmetrical synaptic contacts. The immunoparticles were located mainly at the edge of the membrane specialization and on the extrasynaptic membrane, but only occasionally within the synaptic specialization.

\section{Postembedding immunogold method}

Incubation of sections from Lowicryl-embedded tissue by the postembedding immunogold method revealed the presence of GluR1 and GluR2/3 immunoreactive structures. The GluR4 subunit was not detected with this method, presumably because of the low density of GluR4-immunoreactive structures or, possibly, because of changes in the epitope during embedding. The majority of immunoparticles was located along the membrane of the postsynaptic specialization of asymmetrical synapses (Figs. 8, 9). Immunoparticles for GluR1 and GluR2/3 were present at synapses in both spines and dendrites (Figs. 8, 9). Labeling for GluR1 and GluR2/3 was not distributed evenly along the postsynaptic membrane specialization, and clusters of two or three immunoparticles, usually aligned along the membrane, were often seen (Figs. 8, 9). In all, $42 \%(n=69)$ and 53\% $(n=130)$ of asymmetric axospinous synapses were immunolabeled for the GluR1 and GluR2/3 subunits, respectively; the criterion for immunolabeling was the presence of two or more particles. However, these values are likely to be underestimated because the so-called immunon- egative synapses include those labeled by one particle ( $8 \%$ for GluR1 and 19\% for GluR2/3), which could, in fact, represent the genuine presence of AMPA receptor subunits. We did not include these in the labeled population because of the stochastic nature of immunogold labeling. The distribution of immunoparticles along the postsynaptic membrane in two animals was analyzed at axospinous synapses for GluR1 $(n=30$ synapses, 97 immunometal particles) and GluR2/3 $(n=88$ synapses, 410 immunometal particles) (Fig. 10). The immunoparticles were not distributed homogeneously. At axospinous synapses, they were rarely located in the middle $20 \%$ of the postsynaptic membrane (Fig. 10), representing only 4 and 3\% of immunoparticles for GluR1 and GluR2/3, respectively. In contrast, they were more abundant at the periphery of the synapse: $47 \%$ (GluR1) and $46 \%$ (GluR2/3) of immunoparticles were located in the external $40 \%$ of the synapse. Also, 15\% (GluR1) and 16\% (GluR2/3) of immunoparticles apparently fell outside of the postsynaptic specialization, within a distance of 56 and $52 \mathrm{~nm}$, respectively, equivalent to $20 \%$ of the width of synapse (Fig. 10), but this could be attributable to a steric distortion between the image of the membrane specialization formed from the whole thickness of the section and the most superficial layer available for the antibody.

\section{DISCUSSION}

The results of the present study demonstrate the cellular and subcellular location of AMPA receptor subunits in the neostriatum and their distribution at high resolution in relation to 


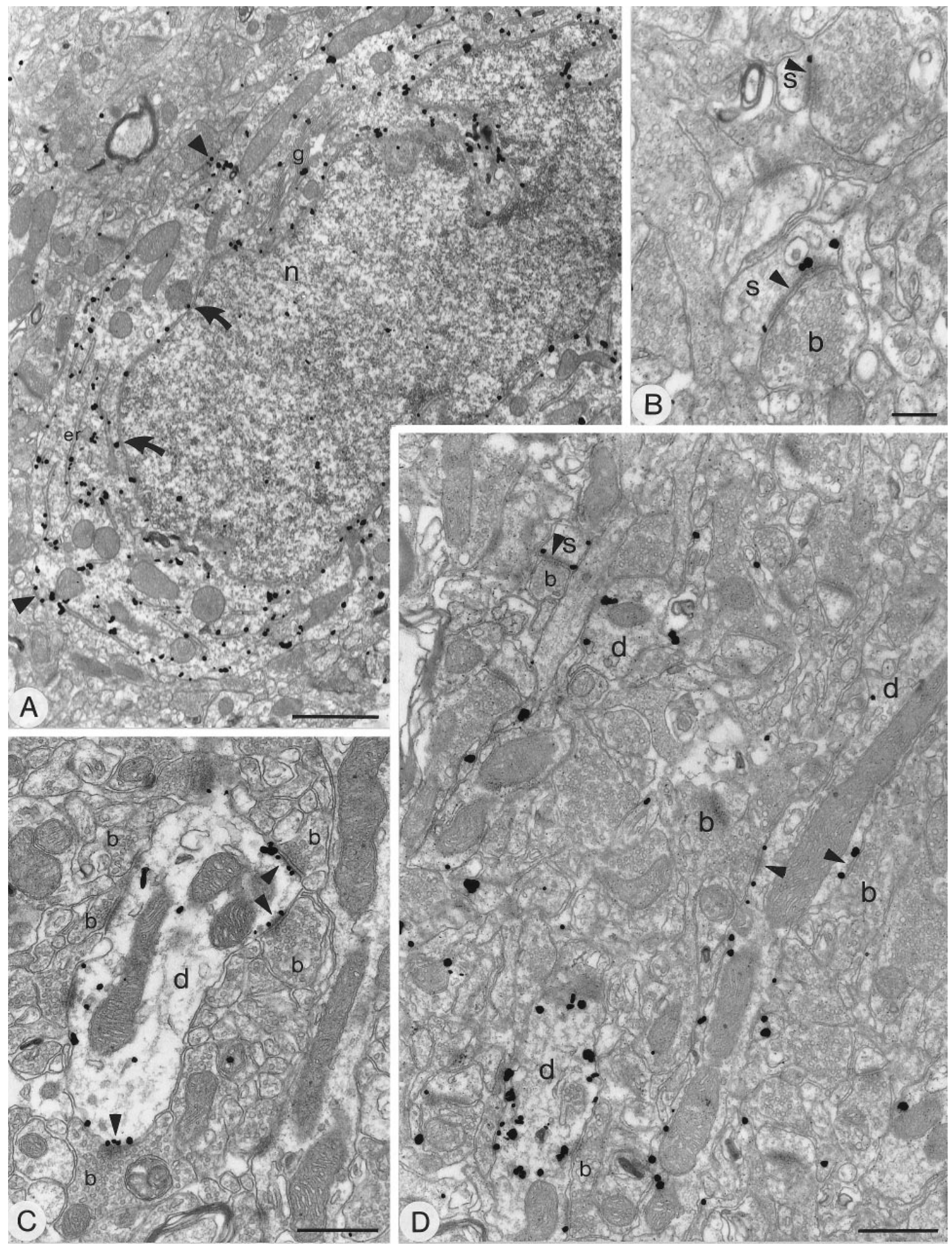

Figure 5. Subcellular localization of GluR1 in the neostriatum using pre-embedding immunogold method with silver intensification. $A$, Immunopositive cell body with an indented nucleus $(n)$ and large volume of cytoplasm, characteristic of striatal interneurons. The immunoparticles are associated with the cytoplasmic surface of the membrane of the endoplasmic reticulum (er) and, albeit to lesser extent, the Golgi apparatus ( $g$ ). Immunoparticles also are located on the external side of the nuclear membrane (curved arrows) and on the internal side of the plasma membrane (arrowheads). B-D, Immunolabeled dendrites $(d)$ and spines $(s)$. The immunoparticles are associated mainly with the internal surface of the plasma membrane. In $C$ and $D$, immunopositive dendrites are surrounded by numerous boutons $(b)$, many of which make asymmetrical synaptic contacts with them, which is a characteristic of interneurons. Immunoparticles are associated with the extrasynaptic plasma membrane and several of the synapses (arrowheads), including axospinous synapses $(s)(B, D)$. The immunoparticles often are localized at the edge of the synaptic specialization, although sometimes (in the spine in $B$ and the top labeled synapse in $C$ ) the immunoparticles appear over the postsynaptic membrane specialization. Scale bars: $A, 1 \mu \mathrm{m} ; B, 0.2 \mu \mathrm{m}$; $C, D, 0.5 \mu \mathrm{m}$. 


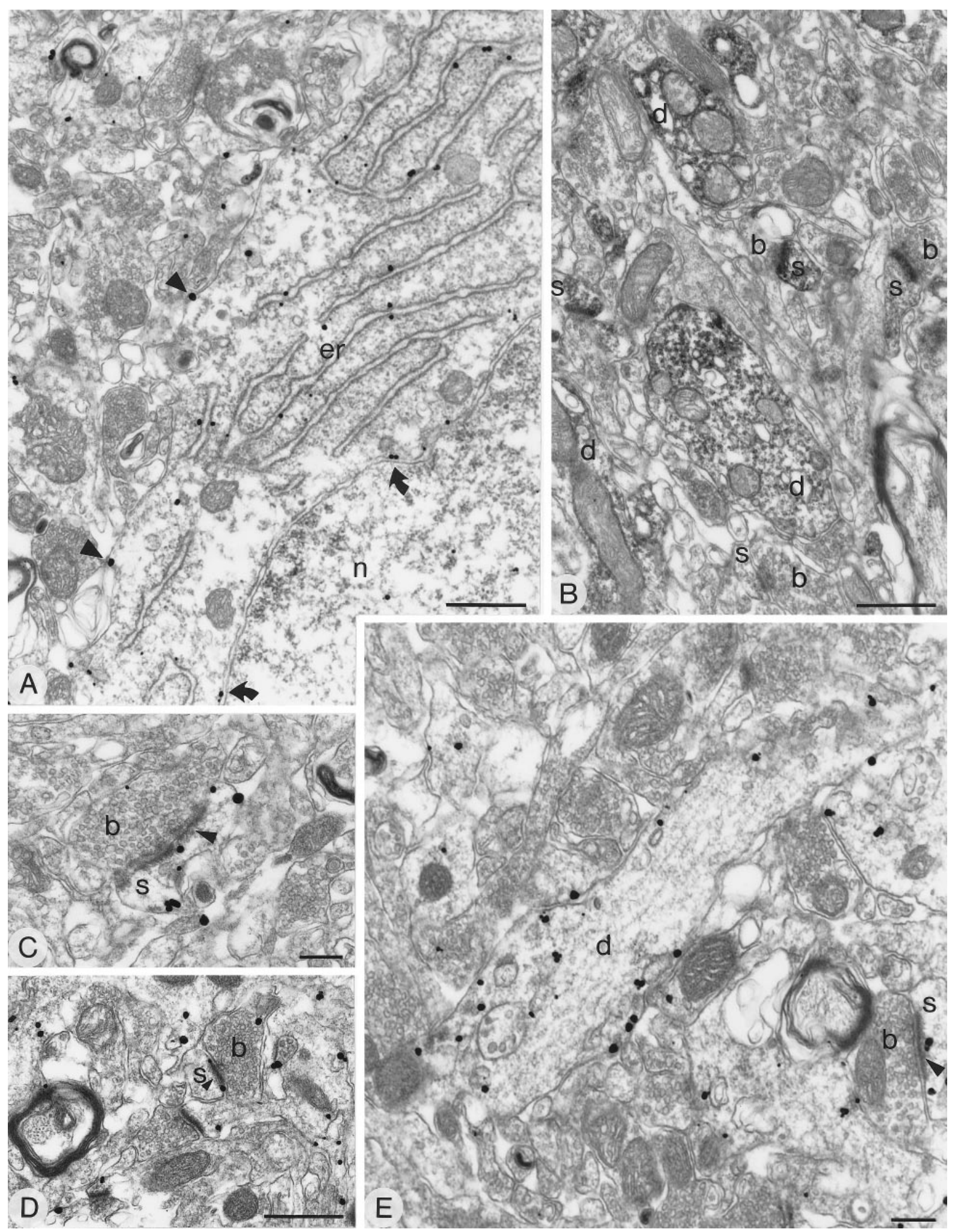

Figure 6. Subcellular localization of GluR2/3 in the neostriatum using pre-embedding immunoperoxidase $(B)$ and immunogold $(A, C-E)$ methods. $A$, Part of an immunoreactive cell body in the neostriatum reacted by the immunogold method. The neuron possesses an indented nucleus $(n)$ and large stacks of endoplasmic reticulum (er), identifying it as an interneuron. Immunoparticles are mainly in association with the cytoplasmic face of endoplasmic reticulum membrane, the cytoplasmic side of nuclear membrane (curved arrows), and on the internal surface of the plasma membrane (arrowheads). B, Immunoreactive dendrites $(d)$ and spines $(s)$ revealed by the immunoperoxidase method. Many of the immunoreactive spines are postsynaptic to boutons (b), forming asymmetrical synapses. $C-E$, Immunoreactive dendrites and spines reacted by the immunogold method. The immunoparticles are located mainly on the internal surface of the plasma membrane of spines and dendrites. Spines receive synapses from boutons forming asymmetrical synapses (arrowheads), and several of them have immunoparticles associated either with the body or the edges of the postsynaptic membrane specialization. Scale bars: $A, B, D, 0.5 \mu \mathrm{m} ; C, E, 0.2 \mu \mathrm{m}$. 

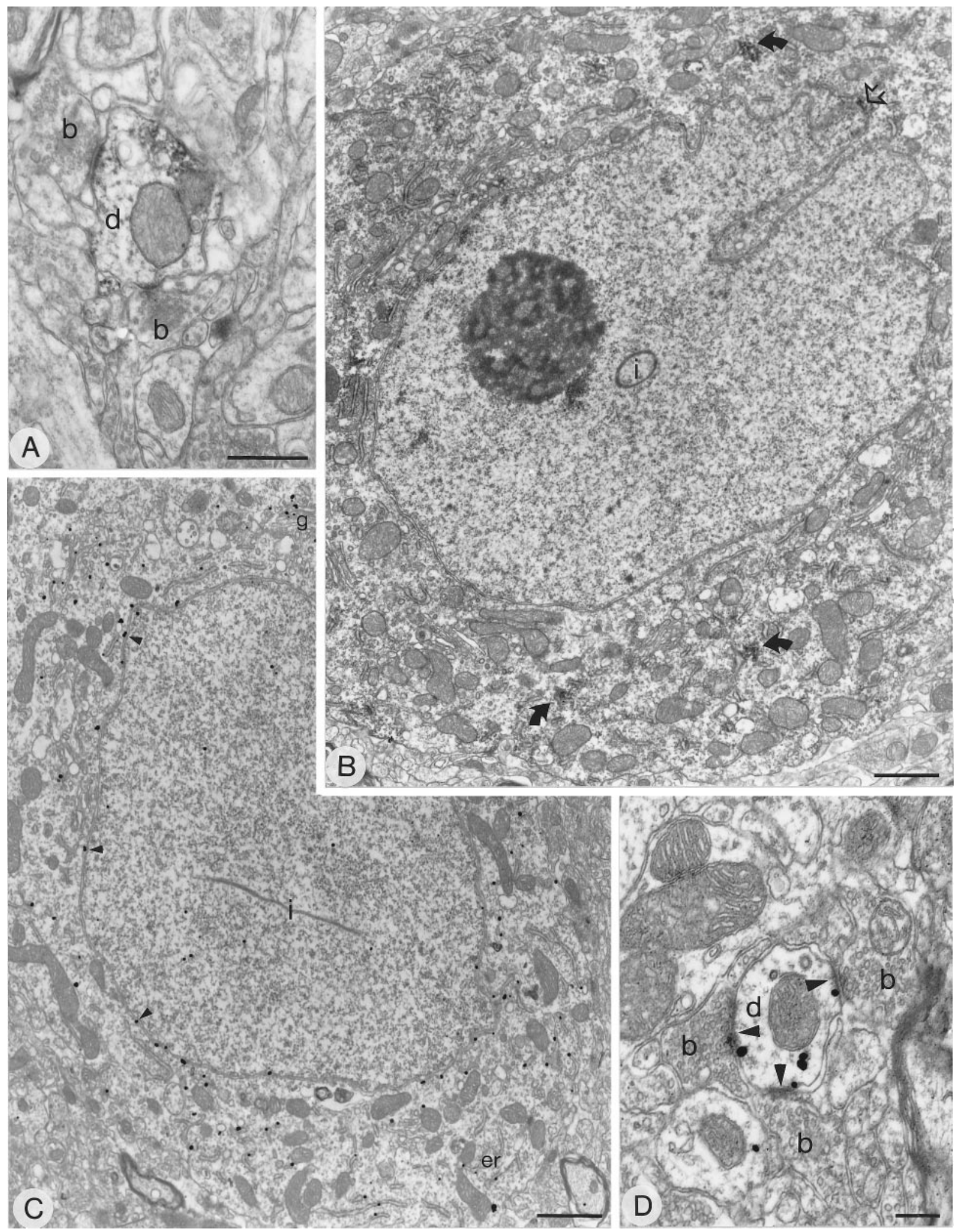

Figure 7. Subcellular localization of GluR4 immunoreactivity in the neostriatum using the pre-embedding immunoperoxidase $(A, B)$ and immunogold $(C, D)$ methods. GluR4 immunolabeling is detected in cell bodies $(B, C)$ and dendrites $(A, D)$. The immunoreactive cells have an indented nucleus $(B)$ and a large volume of cytoplasm and often contain intranuclear inclusions $(i)$, features that are characteristics of striatal interneurons. $B$, Aggregates of immunoperoxidase reaction product are seen in the cytoplasm (curved arrows) and in association with the nuclear membrane (open arrow). $C$, Immunoparticles are associated with the cytoplasmic face of membranes of the endoplasmic reticulum and the Golgi apparatus ( $g$ ) and with the external side of nuclear membrane (small arrowheads). Dendrites that are immunolabeled for GluR4 are surrounded by boutons $(b)$, many of which form asymmetrical synapses $(A, D)$. $D$, Immunoparticles are associated with the edge of the postsynaptic density of the asymmetrical synapses (arrowheads). Scale bars: $A, 0.5 \mu \mathrm{m} ; B, C, 1 \mu \mathrm{m} ; D, 0.2 \mu \mathrm{m}$. 

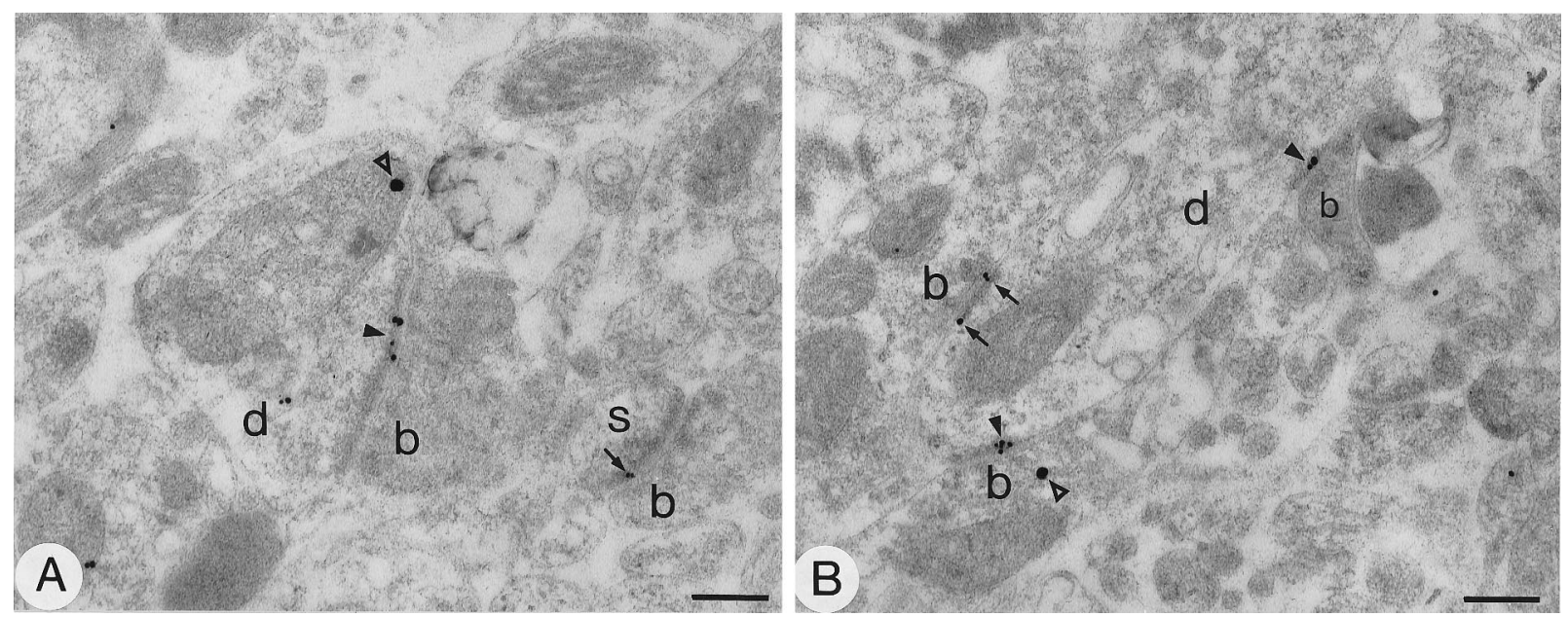

Figure 8. Subcellular localization of GluR1 immunoreactivity in the neostriatum revealed by the postembedding immunogold method with silver intensification. Dendrites $(d)(A, B)$ and a spine $(s)(A)$ are immunolabeled and receive asymmetrical synapses from boutons $(b)$. The small immunoparticles are located mainly on the postsynaptic membrane both within the body of the synaptic specialization (arrowheads) and at its periphery (arrows). The two large particles (open arrowheads) are not attributable to immunolabeling but are a result of the silver intensification process. Scale bars, $0.2 \mu \mathrm{m}$.
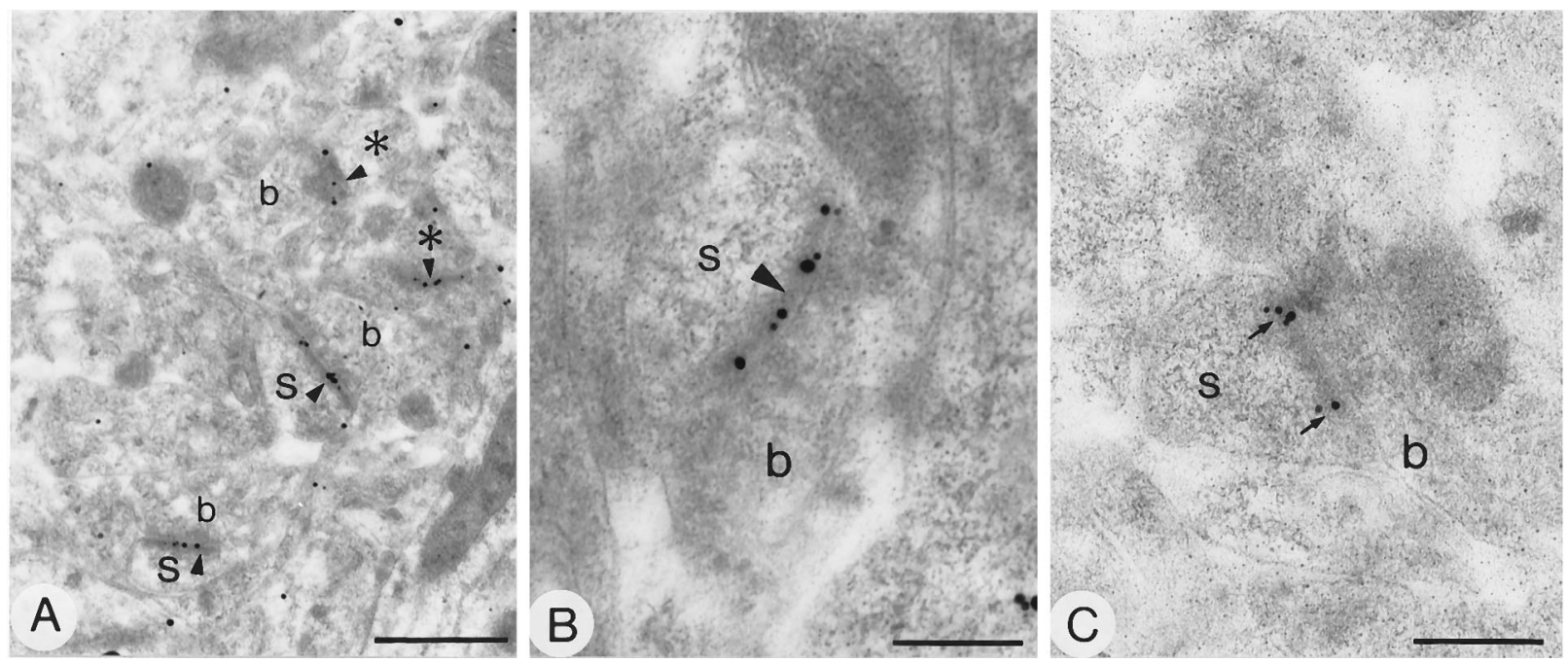

Figure 9. Subcellular localization of GluR2/3 in the neostriatum using the postembedding immunogold method with silver intensification. Electron micrographs show spines $(s)$ immunolabeled for GluR2/3. At low $(A)$ and high $(B, C)$ magnification, immunolabeled spines are seen in synaptic contact with boutons $(b)$ forming asymmetrical synapses (arrowheads). Some postsynaptic profiles (asterisks) could be spines or small dendritic shafts. Immunoparticles occasionally form clusters and seem to be distributed throughout the postsynaptic membrane (arrowheads in $A$ and $B$ ) or are located at the periphery of the postsynaptic specialization (arrows in $C$ ). Scale bars: $A, 0.5 \mu \mathrm{m} ; B, C, 0.2 \mu \mathrm{m}$.

the afferent synaptic terminals. Our observations reveal a heterogeneous distribution of AMPA receptor subunits among different neuronal populations in the neostriatum. The subunits GluR1 and GluR2/3 are expressed by medium spiny efferent neurons and by interneurons, whereas GluR4 is expressed only by interneurons. Immunoreactivity for the receptor subunits on the plasma membrane is commonly, but not exclusively, associated with membranes postsynaptic to axon terminals forming asymmetrical synaptic specializations. Quantitative analysis revealed that GluR1 and GluR2/3 subunits are distributed unevenly along the postsynaptic membrane specialization, being more concentrated at the periphery than at the center of synaptic junctions.

\section{Phenotypes of striatal neurons expressing AMPA receptors}

The first aim of the present study was an attempt to clarify the profile of AMPA receptor subunits expressed by different populations of striatal neurons. In confirmation of previous observations (Albin and Greenamyre, 1992; Petralia and Wenthold, 1992; Tallaksen-Greene et al., 1992; Martin et al., 1993b; TallaksenGreene and Albin, 1994; Chen et al., 1996), our analyses revealed that AMPA receptor subunits are expressed widely within the neostriatum by both projection neurons and interneurons. The majority of neurons expressing GluR1 and GluR2/3 subunits had morphological features typical of medium spiny efferent neurons 


\section{GluR1 and GluR2/3 at axospinous synapses}

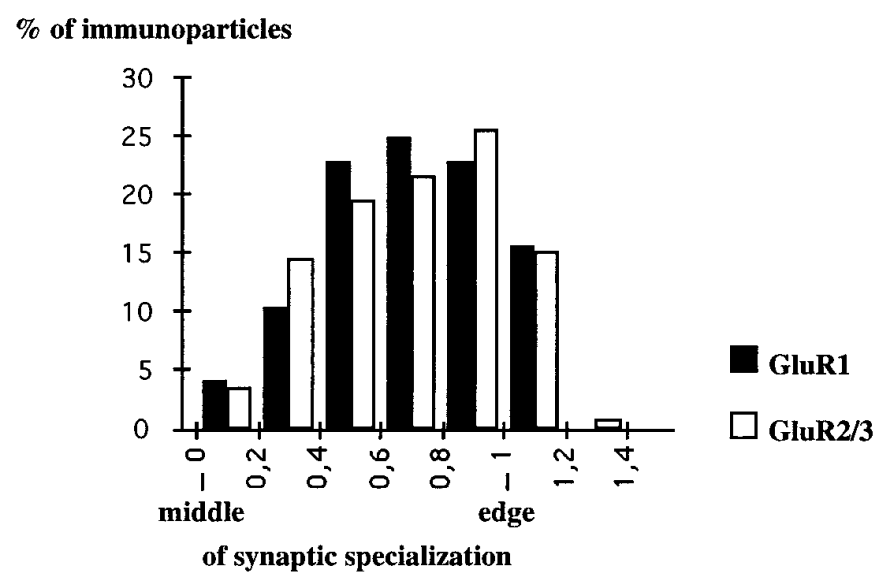

Figure 10. Distribution of immunoparticles for GluR1 and GluR2/3 subunits along the postsynaptic membrane specialization of axospinous synapses labeled by the postembedding immunogold method. A similar distribution of GluR1 and GluR2/3 subunits occurred at axospinous synapses [GluR1, $n=30$ synapses (mean length \pm SEM, $279 \pm 9 \mathrm{~nm}$ ), 97 immunoparticles; GluR2/3, $n=88$ synapses (mean length \pm SEM, $257 \pm$ $19 \mathrm{~nm}$ ), 410 immunoparticles]. Immunoparticles are concentrated at the periphery of the postsynaptic membrane specialization. Only synapses labeled by two or more particles are included in the analysis.

(see Smith and Bolam, 1990), and at least some were characterized as projecting to the substantia nigra. The electron microscopic analyses confirmed that spiny neurons express immunoreactivity for AMPA receptor subunits and, indeed, revealed that at least $50 \%$ of dendritic spines are immunopositive. The data relating to GluR1 are consistent with those of Martin et al. (1993b), but not with those of Tallaksen-Greene and Albin (1994) and Chen et al. (1996), who failed to detect GluR1 immunoreactivity in medium spiny neurons. The reason for this discrepancy is unclear at present; however, it is unlikely to be attributable to differences in antibody preparations, because conflicting observations have been made with antibodies from the same sources. Furthermore, our data showing GluR1 immunoreactivity in spiny neuron perikarya, in spines, and at axospinous synaptic specializations are consistent with in situ hybridization and PCR experiments that have demonstrated mRNA for GluR1 in mediumsized neurons in the rat and human neostriatum (Sommer et al., 1990; Sato et al., 1993; Bernard et al., 1996; Ghasemzadeh et al., 1996).

In agreement with previous observations (Martin et al., 1993b; Tallaksen-Greene and Albin, 1994; Chen et al., 1996), our findings demonstrate immunoreactivity for GluR1, GluR2/3, and GluR4 in neurons with morphological and neurochemical features of striatal interneurons. Thus, cholinergic neurons, identified on the basis of ChAT immunoreactivity, expressed the GluR1 and GluR4 subunits, and all three subunits were detected in GABAergic interneurons identified on the basis of parvalbumin immunoreactivity (see Cowan et al., 1990; Kita et al., 1990). The majority of the other major class of striatal interneuron, identified on the basis of immunoreactivity for NOS, had undetectable levels of the receptor subunits in the soma, despite the fact that at least a proportion of these neurons express mRNA for each of the subunits (Catania et al., 1995). Possibly, there is a low turnover of receptor in the plasma membrane and, consequently, little protein in the somatic endoplasmic reticulum of these cells.
The expression of subunits of the AMPA receptor by different populations of striatal neuron is consistent with data from electrophysiological studies (Wilson, 1993; Kita, 1996) indicating that at least one component of the excitatory drive to striatal spiny neurons is mediated by AMPA receptors. Furthermore, AMPA receptor stimulation has been shown to regulate the release of GABA from efferent neurons, and possibly interneurons, in the neostriatum (Galli et al., 1992; Bianchi et al., 1994).

\section{Subcellular localization of AMPA receptor subunits}

The use of multiple immunocytochemical techniques at both the light and electron microscopic levels allowed us to localize precisely sites of AMPA receptor subunit immunoreactivity. In perikarya the labeling was associated mainly with endoplasmic reticulum, including the nuclear envelope and Golgi apparatus. This distribution is consistent with that found for N-terminaldirected antibodies to the AMPA receptors (Molnar et al., 1993). The labeling of the nuclear membrane is unlikely to be an artifact, because it has been detected consistently with the three antibodies to the AMPA receptor subunit. These receptors are probably in the process of synthesis before being targeted to the plasma membrane and are thus unlikely to be functional. At the level of individual dendrites and spines, the immunogold analyses revealed that most of the immunoreactive sites are present on the plasma membrane and, in agreement with the known topology of the receptor subunits, are on the internal surface of the membrane (Boulter et al., 1990; Sommer et al., 1990; Wenthold et al., 1992; Molnar et al., 1993; Hollmann and Heinemann, 1994; McIlhinney and Molnar, 1996). The pre-embedding immunogold analysis also revealed, in addition to extensive extrasynaptic labeling, that a proportion of immunoparticles was associated with sites on the plasma membrane receiving afferent synaptic boutons that formed asymmetrical membrane specializations. With this approach the majority of the immunoparticles associated with synapses was found at the edges of the synaptic specializations and not within the synaptic specialization itself. In contrast, in the sections incubated by the postembedding immunogold method to reveal GluR1 and GluR2/3 immunoreactive sites, the majority of immunogold particles was localized on the postsynaptic membrane specialization within the active zone, as seen at other synapses (Baude et al., 1993, 1995; Nusser et al., 1994; Kharazia et al., 1996; Matsubara et al., 1996; Popratiloff et al., 1996). Because the postembedding method is less sensitive than pre-embedding methods, these results demonstrate that GluR1 and GluR2/3 immunoreactive sites are at a higher density within the synaptic specializations than at other sites. The discrepancy between preembedding and postembedding immunogold labeling has been observed previously and has been suggested to result from the restricted access of antibodies and/or gold-conjugated antibodies into the active zone in fixed tissue prepared by conventional means (Baude et al., 1995; Nusser et al., 1995).

Ionotropic and metabotropic glutamate receptors are differentially distributed on postsynaptic structures in relation to the synaptic specializations (Baude et al., 1993; Nusser et al., 1994; Kharazia et al., 1996; Lujan et al., 1996; Matsubara et al., 1996; Popratiloff et al., 1996), and it has been suggested that differential distribution of AMPA receptors may occur within the synapse and so may play a role in the development of long-term potentiation (Edwards, 1995). High resolution immunogold analyses have revealed an even distribution of AMPA receptor subunits in synapses of the cerebellum (Nusser et al., 1994), whereas an uneven distribution has been reported in the rat cortex (Kharazia et al., 
1996) or organ of Corti (Matsubara et al., 1996). Our analysis of the distribution of immunoparticles for GluR1 and GluR2/3 subunits along the postsynaptic specialization suggests that in the neostriatum these receptor subunits are distributed unevenly. First, clusters of immunoparticles were observed at different sites within the active zones. Second, the quantitative analysis revealed that the density of immunoparticles for both the GluR1 and GluR2/3 subunits is higher at the periphery of the postsynaptic membrane than at its center, an observation that is consistent with reports in other tissues (Kharazia et al., 1996; Matsubara et al., 1996). It remains to be established whether GluR4, which was not detected by the postembedding technique, also is differentially distributed. We cannot as yet exclude the possibility that, even under postembedding conditions, there is uneven access of immunoreagents to different regions of the synaptic specialization, although the fact that an uneven distribution of AMPA receptor subunits has been observed in different synapses (Kharazia et al., 1996; Matsubara et al., 1996) suggests that this may represent the true distribution.

Our results allow us to suggest the combinations of AMPA receptor subunits that are present at particular synapses. The quantitative analyses revealed that $\sim 50 \%$ of all spines display immunoreactivity for GluR1 and GluR2/3, and when both subunits were revealed together, $62 \%$ of spines were labeled, indicating that GluR1 and GluR2/3 may be at least partially colocalized. For technical reasons these are likely to be underestimates of the true distribution and degree of colocalization. Furthermore, the similarity in the uneven distribution of the two subunits in the postsynaptic membrane suggests that they are combined in the same AMPA receptor. At axodendritic synapses, our results suggest that, with GluR1 and/or GluR2/3, GluR4 may combine to form a functional receptor. The differential subunit combination of the AMPA channels provides a means for the fine tuning of the postsynaptic response with respect to kinetics, desensitization, and $\mathrm{Ca}^{2+}$ permeability (Keinänen et al., 1990; Hollmann et al., 1991; Hume et al., 1991; Gasic and Hollmann, 1992; Keller et al., 1992).

Immunolabeling for GluR1, GluR2/3, and GluR4 at nonsynaptic sites in dendrites and spines was also found. The extrasynaptic localization of AMPA receptor subunits has also been shown in hippocampus (Baude et al., 1995) and for other types of receptors in different systems, e.g., dopamine receptor subtypes in the basal ganglia (Yung et al., 1995; Caillé et al., 1996). The role of extrasynaptic receptors is unclear at present. They may represent receptor subunits in the process of being transported to the synaptic site or they may provide a recruitable pool of receptors; however, as pointed out above, the density at extrasynaptic sites is likely to be much lower than at synaptic sites.

\section{Localization of AMPA receptor subunits in relation to afferent synapses}

One of the main objectives of the present study was to localize the AMPA receptor subunits in relation to the known glutamatergic afferents of the neostriatum; our findings of a differential distribution of the receptor immunoreactivity suggest that there is a selective association of different subunits at different synapses. The major glutamatergic afferents to the neostriatum arise from the cortex and centromedian/parafascicular complex of the thalamus (Gerfen and Wilson, 1996). The majority of terminals derived from the cortex make asymmetrical synaptic contact with the heads of dendritic spines of medium spiny neurons (Somogyi et al., 1981; Smith and Bolam,
1990), and indeed the majority of terminals in contact with the spines is likely to be derived from the cortex. The detection of immunoreactivity for GluR1 and GluR2/3 at asymmetrical axospinous synapses therefore shows that AMPA receptors, including these subunits, mediate, at least in part, the excitatory response to cortical activation, a suggestion that is in line with electrophysiological findings (Wilson, 1993). Cortical terminals also make asymmetrical synaptic contact with the dendritic shafts of GABAergic interneurons (Lapper et al., 1992; Bennett and Bolam, 1994), and, similarly, the majority of terminals derived from centromedian/parafascicular complex of the thalamus make asymmetrical synaptic contacts with dendritic shafts of both medium spiny neurons and cholinergic neurons (Dubé et al., 1988; Xu et al., 1991; Lapper and Bolam, 1992; Sadikot et al., 1992). Our observations thus suggest that only GluR1 and GluR2/3 subunit-containing receptors are in a position to mediate excitatory thalamic inputs to dendritic shafts in spiny neurons, because GluR4 was present only in interneurons. They, also suggest that GluR1, GluR2/3, and GluR4 subunits mediate excitatory inputs from the cortex or thalamus to dendritic shafts of interneurons. Tracing experiments are in progress to determine directly the relationships between thalamic and cortical inputs and the AMPA receptor subunits in the postsynaptic specialization.

\section{REFERENCES}

Albin RL, Greenamyre JT (1992) Alternative excitotoxic hypotheses. Neurology 42:733-738.

Albin RL, Young AB, Penney JB (1989) The functional anatomy of basal ganglia disorders. Trends Neurosci 12:366-374.

Baude A, Nusser Z, Roberts JDB, Mulvihill E, McIlhinney RAJ, Somogyi $\mathrm{P}$ (1993) The metabotropic glutamate receptor (mGluR1 alpha) is concentrated at perisynaptic membrane of neuronal subpopulations as detected by immunogold reaction. Neuron 11:771-787.

Baude A, Nusser Z, Molnar E, McIlhinney RAJ, Somogyi P (1995) High-resolution immunogold localization of AMPA-type glutamate receptor subunits at synaptic and nonsynaptic sites in rat hippocampus. Neuroscience 69:1031-1055.

Bennett BD, Bolam JP (1994) Synaptic input and output of parvalbuminimmunoreactive neurones in the neostriatum of the rat. Neuroscience 62:707-719.

Bergman H, Wichmann T, DeLong MR (1990) Reversal of experimental parkinsonism by lesions of the subthalamic nucleus. Science 249:1436-1438.

Bernard V, Gardiol A, Faucheux B, Bloch B, Agid Y, Hirsch EC (1996) Expression of glutamate receptors in the human and rat basal ganglia. Effect of the dopaminergic denervation on AMPA receptor gene expression in the striatopallidal complex in Parkinson's disease and rat with 6-OHDA lesion. J Comp Neurol 368:553-568.

Bianchi L, Sharp T, Bolam JP, Della Corte L (1994) The effect of kainic acid on the release of GABA in rat neostriatum and substantia nigra. NeuroReport 5:1233-1236.

Blandini F, Porter RHP, Greenamyre JT (1996) Glutamate and Parkinson's disease. Mol Neurobiol 12:73-94.

Boulter J, Hollmann M, O'Shea-Greenfield A, Hartley M, Deneris ES, Maron C, Heinemann S (1990) Molecular cloning and functional expression of glutamate receptor subunit genes. Science 249:1033-1037.

Boulter J, Bettler B, Dingledine R, Egebjerg J, Hartley M, HermansBorgmeyer I, Hollmann M, Hume RI, Rogers S, Heinemann S (1992) Molecular biology of the glutamate receptors. Clin Neuropharmacol 15:60A-61A.

Brose N, Huntley GW, Stern-Bach Y, Sharma G, Morrison JH, Heinemann SF (1994) Differential assembly of coexpressed glutamate receptor subunits in neurons of rat cerebral cortex. J Biol Chem 269:16780-16784.

Caillé I, Dumartin B, Bloch B (1996) Ultrastructural localization of D1 dopamine receptor immunoreactivity in rat. Striatonigral neurons and its relation with dopaminergic innervation. Brain Res 730:17-31.

Catania MV, Tölle TR, Monyer H (1995) Differential expression of 
AMPA receptor subunits in NOS-positive neurons of cortex, striatum, and hippocampus. J Neurosci 15:7046-7061.

Chen Q, Veenman CL, Reiner A (1996) Cellular expression of ionotropic glutamate receptor subunits on specific striatal neuron types and its implication for striatal vulnerability in glutamate receptor-mediated excitotoxicity. Neuroscience 73:715-731.

Cowan RL, Wilson CJ, Emson PC, Heizmann CW (1990) Parvalbumincontaining GABAergic interneurons in the rat neostriatum. J Comp Neurol 302:197-205.

Cozzari C, Howard J, Hartman B (1990) Analysis of epitopes on choline acetyltransferase (ChAT) using monoclonal antibodies (mAbs). Soc Neurosci Abstr 16:200.

DiFiglia M (1990) Excitotoxic injury of the neostriatum: a model for Huntington's disease. Trends Neurosci 13:286-289.

Dubé L, Smith AD, Bolam JP (1988) Identification of synaptic terminals of thalamic and cortical origin in contact with distinct medium-sized spiny neurons in the rat neostriatum. J Comp Neurol 267:322-335.

Edwards FA (1995) LTP — a structural model to explain the inconsistencies. Trends Neurosci 18:250-255.

Galli T, Desce JM, Artaud F, Kemel ML, Cheramy A, Glowinski J (1992) Modulation of GABA release by $\alpha$-amino-3-hydroxy-5-methylisoxazole4-proprionate and $N$-methyl-D-aspartate receptors in matrix-enriched areas of the rat striatum. Neuroscience 50:769-780.

Gasic GP, Hollmann M (1992) Molecular neurobiology of glutamate receptors. Annu Rev Physiol 54:507-536.

Gerfen CR, Wilson CJ (1996) The basal ganglia. In: Handbook of chemical neuroanatomy. Integrated systems of the CNS, Part III, Vol 12 (Björklund A, Hökfelt T, Swanson LW, eds), pp 369-466. Amsterdam: Elsevier Science.

Ghasemzadeh MB, Sharma S, Surmeier DJ, Eberwine JH, Chesselet MF (1996) Multiplicity of glutamate receptor subunits in single striata neurons: an RNA amplification study. Mol Pharmacol 49:852-859.

Herbison AE, Simonian SX, Norris PJ, Emson PC (1996) Relationship of neuronal nitric oxide immunoreactivity to $\mathrm{GnRH}$ neurons in the ovariectomized and intact female rat. J Neuroendocrinol 8:73-82.

Hollmann M, Heinemann S (1994) Cloned glutamate receptors. Annu Rev Neurosci 17:31-108.

Hollmann M, Hartley M, Heinemann S (1991) $\mathrm{Ca}^{2+}$ permeability of KA-AMPA-gated glutamate receptor channel depends on the subunit composition. Science 252:851-853.

Hume RI, Dingledine R, Heinemann SF (1991) Identification of a site in glutamate receptor subunits that controls calcium permeability. Science 253:1028-1031.

Huntley GW, Vickers JC, Morrison JH (1994) Cellular and synaptic localization of NMDA and non-NMDA receptor subunits in neocortex: organizational features related to cortical circuitry, function, and diseases. Trends Neurosci 17:536-543.

Keinänen K, Wisden W, Sommer B, Werner P, Herb A, Verdoorn TA, Sakmann B, Seeburg PH (1990) A family of AMPA-selective glutamate receptors. Science 249:556-560.

Keller BU, Hollmann M, Heinemann S, Konnerth A (1992) Calcium influx through subunits GluR1/GluR3 of kainate/AMPA receptor channels is regulated by cAMP-dependent protein kinase. EMBO J 11:891-896.

Kharazia VN, Phend KD, Rustioni A, Weinberg RJ (1996) EM localization of AMPA and NMDA receptor subunits at synapses in rat cerebral cortex. Neurosci Lett 210:37-40.

Kita H (1996) Glutamatergic and GABAergic postsynaptic responses of striatal spiny neurons to intrastriatal and cortical stimulation recorded in slice preparations. Neuroscience 70:925-940.

Kita H, Kosaka T, Heinmann CW (1990) Parvalbumin-immunoreactive neurons in the rat neostriatum: a light and electron microscopic study. Brain Res 536:1-15.

Lapper SR, Bolam JP (1992) Input from the frontal cortex and the parafascicular nucleus to cholinergic interneurons in the dorsal striatum of the rat. Neuroscience 51:533-545.

Lapper SR, Smith Y, Sadikot AF, Parent A, Bolam JP (1992) Cortical input to parvalbumin-immunoreactive neurones in the putamen of the squirrel monkey. Brain Res 580:215-224.

Lujan R, Nusser Z, Roberts JDB, Shigemoto R, Somogyi P (1996) Perisynaptic location of metabotropic glutamate receptors mGluR1 and mGluR5 on dendrites and dendritic spines in the rat hippocampus. Eur J Neurosci 8:1488-1500.

Maione S, Biggs CS, Rossi F, Fowler LJ, Whitton PS (1995) $\alpha$-Amino3-hydroxy-5-methyl-4-isoxazolepropionate receptors modulate dopa- mine release in rat hippocampus and striatum. Neurosci Lett 193:181-184.

Martin LJ, Blackstone CD, Huganir RL, Price DL (1993a) The striatal mosaic in primates: striosomes and matrix are differentially enriched in ionotropic glutamate receptor subunits. J Neurosci 13:782-792.

Martin LJ, Blackstone CD, Levey AI, Huganir RL, Price DL (1993b) AMPA glutamate receptor subunits are differentially distributed in rat brain. Neuroscience 53:327-358.

Matsubara A, Laake JH, Davanger S, Usami SI, Ottersen OP (1996) Organization of AMPA receptor subunits at a glutamate synapse: a quantitative immunogold analysis of hair cell synapses in the rat organ of Corti. J Neurosci 16:4457-4467.

McIlhinney RAJ, Molnar E (1996) Characterization, cell-surface expression and ligand-binding properties of different truncated N-terminal extracellular domains of the ionotropic glutamate receptor subunit GluR1. Biochem J 315:217-225.

Molnar E, Baude A, Richmond SA, Patel PB, Somogyi P, McIlhinney RAJ (1993) Biochemical and immunohistochemical characterization of anti-peptide antibodies to a cloned GluR1 glutamate receptor subunit. Cellular and subcellular distribution in the rat forebrain. Neuroscience 53:307-326.

Nakanishi S, Masu M (1994) Molecular diversity and functions of glutamate receptors. Annu Rev Biophys Biomol Struct 23:319-348.

Nakanishi N, Schneider NA, Axel R (1990) A family of glutamate receptor genes: evidence for the formation of heteromultimeric receptors with distinct channel properties. Neuron 5:569-581.

Nusser Z, Mulvihill E, Streit P, Somogyi P (1994) Subsynaptic segregation of metabotropic and ionotropic glutamate receptors as revealed by immunogold localization. Neuroscience 61:421-427.

Nusser Z, Roberts JDB, Baude A, Richards JG, Sieghart W, Somogyi P (1995) Immunohistochemical localization of the alpha 1 and beta $2 / 3$ subunits of the $\mathrm{GABA}_{\mathrm{A}}$ receptor in relation to specific GABAergic synapses in the dentate gyrus. Eur J Neurosci 7:630-646.

Olucha F, Martinez-Garcia F, Lopez-Garcia C (1985) A new stabilizing agent for the tetramethylbenzidine (TMB) reaction product in the histochemical detection of horseradish peroxidase (HRP). J Neurosci Methods 13:131-138.

Paxinos A, Watson C (1986) The rat brain in stereotaxic coordinates. Sydney: Academic.

Petralia RS, Wenthold RJ (1992) Light and electron microscopic localization of AMPA selective glutamate receptors in the rat brain. J Comp Neurol 318:329-354.

Pollak P, Benabid AL, Gross C, Gao DM, Laurent A, Benazzouz A, Hoffmann D, Gentil M, Perret J (1993) Effet de la stimulation du noyau sous-thalamique dans la maladie de Parkinson. Rev Neurol 149:175-176.

Popratiloff A, Weinberg RJ, Rustioni A (1996) AMPA receptor subunits underlying terminals of fine-caliber primary afferent fibers. J Neurosci 16:3363-3372.

Puchalski RB, Louis JC, Brose N, Traynelis SF, Egebjerg J, Kukekov V, Wenthold RJ, Rogers SW, Lin F, Moran T, Morrison JH, Heinemann SF (1994) Selective RNA editing and subunit assembly of native glutamate receptors. Neuron 13:131-147.

Sadikot AF, Parent A, Smith Y, Bolam JP (1992) Efferent connections of the centromedian and parafascicular nuclei in the squirrel monkey. A light and electron microscopic study of the thalamostriatal projection in relation to striatal heterogeneity. J Comp Neurol 320:228-242.

Sato K, Kiyama H, Tohyama M (1993) The differential expression pattern of messenger RNAs encoding non- $N$-methyl-D-aspartate glutamate receptor subunits (GluR1-4) in the rat brain. Neuroscience 52:515-539.

Smith AD, Bolam JP (1990) The neural network of the basal ganglia as revealed by the study of synaptic connections of identified neurones. Trends Neurosci 13:259-265.

Sommer B, Keinänen K, Verdoorn TA, Wisden W, Burnashev N, Herb A, Kohler M, Takagi T, Sakmann B, Seeburg PH (1990) Flip and flop-a cell-specific functional switch in glutamate-operated channels of the CNS. Science 249:1580-1585.

Somogyi P, Bolam JP, Smith AD (1981) Monosynaptic cortical input and local axon collaterals of identified striatonigral neurons. A light and electron microscopic study using the Golgi-peroxidase transportdegeneration procedure. J Comp Neurol 195:567-584.

Tachibana M, Wenthold RJ, Morioka H, Petralia RS (1994) Light and electron microscopic immunocytochemical localization of AMPAselective glutamate receptors in the rat spinal cord. J Comp Neurol 344:431-454. 
Tallaksen-Greene SJ, Albin RL (1994) Localization of AMPA-selective excitatory amino acid receptor subunits in identified populations of striatal neurons. Neuroscience 61:509-519.

Tallaksen-Greene SJ, Wiley RG, Albin RL (1992) Localization of striatal excitatory amino acid binding site subtypes to striatonigral projection neurons. Brain Res 594:165-170.

von Krosigk M, Smith AD (1991) Descending projections from the substantia nigra and retrorubral field to the medullary and pontomedullary reticular formation. Eur J Neurosci 3:260-273.

Wenthold RJ, Yokotani N, Doi K, Wada K (1992) Immunochemical characterization of the non-NMDA glutamate receptor using subunitspecific antibodies. J Biol Chem 267:501-507.

Wenthold RJ, Petralia RS, Blahos J, Niedzielski AS (1996) Evidence for multiple AMPA receptor complexes in hippocampal CA1/CA2 neurons. J Neurosci 16:1982-1989.
Wilson CJ (1993) The generation of natural firing patterns in neostriatal neurons. Prog Brain Res 99:277-297.

Xu ZC, Wilson CJ, Emson PC (1991) Restoration of thalamostriatal projections in rat neostriatal grafts: an electron microscopic analysis. J Comp Neurol 303:22-34.

Young AB, Greenamyre JT, Hollingsworth Z (1988) NMDA receptor losses in putamen from patients with Huntington's disease. Science 241:981-983.

Yung KKL, Bolam JP, Smith AD, Hersch SM, Ciliax BJ, Levey AI (1995) Ultrastructural localisation of D1 and D2 dopamine receptors in the basal ganglia of the rat by light and electron microscopic immunocytochemistry. Neuroscience 65:709-730.

Zorumski CF, Thio LL (1992) Properties of vertebrate glutamate receptors: calcium mobilization and desensitization. Prog Neurobiol 39:295-336. 